\title{
MEAT PRODUCTIVITY THE QUALITY OF RAW MEAT OF ANIMALS OF KALMYK BREED NEW FACTORY LINES
}

\section{МЯСНАЯ ПРОДУКТИВНОСТЬ И КАЧЕСТВО МЯСНОГО СЫРЫЯ ЖИВОТНЫХ КАЛМЫЦКОЙ ПОРОДЫ НОВЫХ ЗАВОДСКИХ ЛИНИЙ}

\author{
Pristupa V.N. ${ }^{1}$, Kolosov A.Yu. ${ }^{1}$, Torosayn D.V. ${ }^{1}$, Kolosov Yu. A. ${ }^{1}$, \\ Orlova O.N. ${ }^{2}$, Dmitrieva L.S. ${ }^{2}$, Eroshenko V.I. ${ }^{2}$, Skripnik L.V. ${ }^{2}$. \\ Don state agrarian University, Persianovskiy, Rostov region, Russia \\ 2 The North-Caucasian branch of the V.M. Gorbatov All-Russian Meat Research Institute, Rostov-Don, Russia
}

Ключевые слова: крупныц̆ рогатыцй скот, калмыцзкая порода, новые линии, мясная продуктивность, говядина, показатели, аминокислота.

\section{Аннотация}

Представлены результаты исследований новых заводских линий калмыцкой породы крупного рогатого скота: Пирата 6626, Похвального 8643 и Ожога 6136.

Для оценки мясной продуктивности, морфологического состава туш, физико-химического, аминокислотного и жирнокислотного составов мышечной ткани был проведен контрольный убой молодняка (бычков) в 15-месячном возрасте разной линейной принадлежности, которьй показал более высокую массу парной туши у бычков тинии Пирата 6626 - 215,9к2, Похвального 8643 и Ожога 6136 ниже в среднем 212,5кг. По убойной массе и убойному выходу бычки новых линий отличались незначительно и составили соответственно 221,4-223,9 кг (56,0\%- 56,4\%). Туши всех подопьтнных животных при убое характеризовались хорошим выходом обваленного мяса (82,3-82,6\%) при относительно небольшом содержании костей $(17,4-17,7 \%)$.У бычков линии Пирата 6626 влагосвязывающяа способность выше на 1,96 и 1,09\%, а потери сока при варке ниже на 0,76 и 0,90\%, чем у бъчков линии Похвального 8643 и Ожога 6136.

Анализ химического состава обваленного мяса показал более высокое содержание белка в мясе у бычков линии Похвального 8643 (23,41\%), чем у бычков тинии Пирата 6626 (20,95\%) и Ожога 6136 (21,75\%). Содержание жира в мясе у бычков линии Пирата 6626 и Ожога 6136 было выше, чем у бычков линии Похвального 8643 и составило 2,84 и 2,99\%.

В белках животных трёх тиний содержание незаменимых аминокислот превышает рекомендуемый ФАО/ВОЗ для человека, не имеется лимитирующих аминокислот.

Максимальный аминокислотный скор тицина в белках надблюдался у животных тинии Пирата 6626 - на 3,6\% выше линии Похвального 8643 и на 7,9\% - линии Ожога 6136, лейиина и изолейинна в белках больще в линиях Пирата 6626 и Ожога 6136.

Аминокислота валин по расчетам скора была больше в белках мыши, бычков тинии Пирата 6626, её скор составил 120,0\%, в белках Похвального 8643 - 110,0\%, Ожога 6136 $114,0 \%$.

Скор аминокислоты метионин имел наименьшую разнииу с эталонным белком у бычков тинии Похвального 8643. Минимальная разница скора фенилаланина с эталонным белком наблюдалась также у бычков линии Похвального 8643 и составила 5,0\%.
Keywords: cattle, Kalmyk breed, new lines, meat productivity, beef, indicators, amino acid.

\section{Abstract}

The results of research are presented for new stud lines of Kalmyk cattle: Pirat 6626, Pokhvalny 8643, and Ozhog 6136.

To assess meat productivity, carcass morphological composition, physical and chemical properties, amino acid and fatty acid compositions of muscle tissue, control slaughter of young bulls (15 months old) of different breed lines was carried out. The slaughter showed a higher weight of fresh carcass in bulls of Pirat 6626 line, which was $215.9 \mathrm{~kg}$. Weight of Pokhvalny 8643 and Ozhog 6136 lines was lower, $212.5 \mathrm{~kg}$ in average. Bulls of new lines insignificantly differed by the dressed weight and slaughter yield amounted to 221.4 to $223.9 \mathrm{~kg}$ (56.0\% to 56.4\%), respectively. At slaughter, carcasses of all experimental animals were characterized by a good yield of deboned meat ( 82.3 to $82.6 \%$ ) with a relatively small bone content (17.4 to 17.7\%). Compared to bulls of Pokhvalny 8643 and Ozhog 6136 lines, Pirat 6626 line had water binding capacity higher by 1.96 and $1.09 \%$, and juice loss during cooking was lower by 0.76 and $0.90 \%$.

Chemical composition analysis of deboned meat showed a higher protein content in meat from Pokhvalny 8643 bulls (23.41\%) than from Pirat 6626 (20.95\%) and Ozhog 6136 (21.75\%) lines. Fat content in the meat of Pirat 6626 and Ozhog 6136 bulls was higher than in Pokhvalny 8643 bulls and amounted to 2.84 and $2.99 \%$. In proteins of animals from all three lines, the content of essential amino acids exceeds the levels recommended by FAO/WHO for humans; there are no limiting amino acids.

The maximum lysine amino acid score was observed in proteins of Pirat 6626 animals, which was higher by 3.6\% than in Pokhvalny 8643 line and by 7.9\% than in Ozhog 6136 line; leucine and isoleucine were higher in proteins of Pirat 6626 and Ozhog 6136 lines. Valine amino acid score was higher in muscle proteins of Pirat 6626 bulls (120.0\%), than in the proteins of Pokhvalny 8643 (110.0\%) and Ozhog 6136 (114.0\%) lines.

In Pokhvalny 8643 bulls, methionine amino acid score had the smallest difference with the reference protein. The minimal difference in phenylalanine amino acid score with the reference protein was also observed in Pokhvalny 8643 bulls and amounted to $5.0 \%$. 
По результатам расчета биологической иенности белка более сбалансированным соотношением незаменимых аминокислот обладает линия Похвального 8643 - 89,7\%, тогда как у тинии Пирата 6626 и Ожога 6136 - 81,4 и 81,7\% coответственно.

Различия в составе жирных кислот во внутримышечном жире бычков всех линий несущественные, но прослеживалось превосходство показателей тинии Похвального 8643 по содержанию полиненасыщенных кислот на 0,48-0,33\%.

Дегустационная оценка качества отварного мяса-говядины и мясного бульона от молодняка крупного рогатого скота калмыцкой породы новых тиний - «хорочее» и «очень хорошее».

\section{Введение}

Мясо и мясные продукты - неотъемлемая часть ежедневного рациона человека, поэтому первоочередной задачей мясоперерабатывающей промышленности является максимальное удовлетворение запросов потребителя в количестве и качестве мясной продукции.

Для увеличения производства говядины важнейшим средством служит развитие специализированного мясного скотоводства. Его эффективность зависит от правильного подбора для разведения хорошо приспособленных импортных и отечественных пород. Среди специализированного мясного скота в России большое значение имеет калмыцкая порода, совершенствование которой проводится различными методами, в том числе посредством создания новых заводских линий [1-3].

Калмыцкая порода крупного рогатого скота мясного направления, выведенная длительным совершенствованием скота, приведенного кочевыми калмыцкими племенами около 350 лет назад из западной части Монголии, неприхотлива к кормам и условиям содержания, стойко сохраняет упитанность во время летних засух и длительных зимовок. Животные крепкой конституции, гармоничного сложения. Мясо обладает высокими вкусовыми качествами. Калмыцкую породу используют для улучшения мясных качеств молочных и молочно-мясных пород, а также для промышленного скрещивания. Разводят в Республике Калмыкия, Ростовской, Астраханской областях, Ставропольском крае и других районах РФ [4-5].

Разведение по линиям является основным элементом углубленной селекции, организационным мероприятием необходимой качественной

дифференциации и генеалогической структуризации стада, внутрипородного типа и породы, как при чистопородном разведении, так и в процессе воспроизводительного скрещивания [6-7].

В Южном федеральном округе учеными Донского государственного аграрного университета проводится целенаправленная работа по созданию новых селекционных линий в мясном скотоводстве. В результате в 2015 году Минсельхозпродом Ростовской области
According to the results of protein biological value calculation, Pokhvalny 8643 line has more balanced ratio of essential amino acids of 89.7\%, while Pirat 6626 and Ozhog 6136 lines show ratios of $81.6 \%$ and $81.7 \%$, respectively.

Differences in fatty acid composition of intramuscular fat from bulls of all three lines are insignificant, but Pokhvalny 8643 line shows some superiority in the content of polyunsaturated acids by 0.48 to $0.33 \%$.

Sensory assessment of boiled beef and meat broth quality from new lines of Kalmyk young cattle was «good» and «very good».

\section{Introduction}

Meat and meat products are an integral part of daily diet in humans, so the primary goal of the meat-processing industry is to meet consumer's requests for the quantity and quality of meat products.

To increase the production of beef, the most important activity is the development of specialized beef cattle breeding. Its effectiveness depends on the correct selection of well-adapted imported and domestic breeds. Among the specialized beef cattle in Russia, Kalmyk breed is of great importance, because its improvement is carried out by various methods including the creation of new stud lines [1-3].

The Kalmyk breed of beef cattle developed by the long-term improvement of livestock brought by nomadic Kalmyk tribes from the western part of Mongolia about 350 years ago is unpretentious to fodder and maintenance conditions, stably keeps fatness during summer droughts and long winter periods. These animals are of sound constitution and harmonious appearance; meat has high taste qualities. Kalmyk breed is used to improve meat quality of dairy and beef-dairy breeds, as well as for industrial crossbreeding. These animals are bred in the Republic of Kalmykia, Rostov, Astrakhan, Stavropol and other regions of the Russian Federation [4-5].

Breeding within lines is the main component of the advanced selection and is used as the organizational measure of necessary qualitative differentiation and genealogical structuring of herd, intra-breed type and breed, both in pure breeding and in the process of reproductive crossbreeding [6-7].

In the Southern Federal District, scientists of the Don State Agrarian University carry out targeted work to create new breeding lines in beef cattle. As a result, in 2015 the Ministry of Agriculture and Food of the Rostov region carried out approbation and approved new stud lines 
была проведена апробация и утверждены новые заводские линии калмыцкой породы крупного рогатого скота: Пирата 6626, Похвального 8643 и Ожога 6136.

Целью исследования являлось:

- сравнительная оценка мясной продуктивности бычков калмыцкой породы разной линейной принадлежности;

- изучение морфологических, физико-химических показателей мяса крупного рогатого скота новых заводских линий калмыцкой породы, аминокислотного состава мышечной ткани, состава жирных кислот внутримышечного жира.

\section{Материалы и методы}

Объектами исследований являлись:

- молодняк-бычки калмыцкой породы новых заводских линий: Пирата 6626, Похвального 8643 и Ожога 6136;

- продукты переработки молодняка крупного рогатого скота: туши и говядина.

Для изучения мясной продуктивности из массива животных каждой линии было отобрано по 3 головы бычков в 15-месячном возрасте, выращенных в СПК «Племзавод «МИР» (с. Ремонтное Ростовской области), отражающие средний уровень продуктивности своей линии.

Контрольный убой подопытных бычков был проведен в производственных условиях СПК «Племзавод «МИР».

Исследования по изучению качества мяса бычков калмыцкой породы разной линейной принадлежности были проведены в лабораториях Всероссийского научно-исследовательского института мясной промышленности им. В.М. Горбатова (Москва), СевероКавказский филиал Всероссийского научно-исследовательского института мясной промышленности им. B.M. Горбатова (Ростов-на-Дону) и Донского государственного аграрного университета» (п. Персиановский Ростовской обл.).

Мясную продуктивность изучали по результатам контрольного убоя животных по общепринятым методикам Всероссийского научно-исследовательского института мясной промышленности им. В.М. Горбатова. Убойные качества определяли по предубойной живой массе, массе туши, массе внутреннего жирасырца, убойной массе и убойному выходу.

Морфологический состав туш изучали путём обвалки туш после охлаждения в течение 24 часов при температуре от 0 до $+4^{\circ} \mathrm{C}$. При этом изучали соотношение мякоти и костей.

Химический состав обваленного мяса подопытных животных определяли по общепринятой методике, в т.ч. для определения общей влаги - ГОСТ 33319; массовой доли общей золы - ГОСТ 31727-2012; содержания белка - метод Кьельдаля (ГОСТ 25011-81); жира - по Сокслету (ГОСТ 23042-86) [8-9]. of Kalmyk breed: Pirat 6626, Pokhvalny 8643 and Ozhog 6136.

The purpose of the study was:

- comparative evaluation of meat productivity in young Kalmyk bulls of different lines;

- study of amino acid composition of muscle tissue, fatty acid composition of intramuscular fat, morphological, physical and chemical indicators of meat in new stud lines of Kalmyk breed.

\section{Materials and methods}

The objects of research were:

- young Kalmyk bulls of new stud lines: Pirat 6626, Pokhvalny 8643 and Ozhog 6136;

- products of cattle processing: carcasses and beef.

To study meat productivity in young bulls, 3 animals (15 months of age) grown in SPK «Plemzavod MIR» farm (in the village of Remontnoye, Rostov region) and reflecting the average level of productivity of their line were taken form of each line.

The control slaughter of experimental young bull was carried out under the industrial conditions at SPK «Plemzavod MIR» farm.

Studies to evaluate meat quality of young Kalmyk bulls of different lines were conducted in the laboratories of the V.M. Gorbatov All-Russian Meat Research Institute (Moscow), North-Caucasian Branch of the V.M. Gorbatov AllRussian Meat Research Institute (Rostov-on-Don) and the Don State Agrarian University (the village of Persianovskiy, Rostov region).

Meat production was studied based on the results of control slaughter of animals according to the generally accepted methods of the V.M. Gorbatov All-Russian Meat Research Institute. The carcass parameters were determined by pre-slaughter live weight, carcass weight, internal raw fat weight, dressed weight and slaughter yield.

Morphological composition of the carcasses was studied by deboning the carcasses after chilling for 24 hours at a temperature of 0 to $4{ }^{\circ} \mathrm{C}$. At the same time, the ratio of flesh and bones was studied.

Chemical composition of deboned meat of the experimental animals was determined according to the generally accepted methods: to determine total moisture content, GOST 33319 was used; total ash content - GOST 317272012; protein content - Kjeldahl method (GOST 25011-81); fat content according to Soxlet - GOST 23042-86 [8-9]. 
Исследовались образцы средней пробы измельченного мяса, пропущенного через волчок (мясорубку) с диаметром отверстий решетки 3 мм, и внутримышечного жира, полученные от бычков трех групп. Измельченное мясо хорошо перемешивали и из него отбирали среднюю пробу 400 г.

Содержание аминокислот и их соотношение изучали с использованием системы капиллярного электрофореза «Капель 105/105М». Сравнение проводили согласно аминокислотной шкале Продовольственного комитета Всемирной организации здравоохранения (ФАО/ВОЗ).

Выделение липидов из образцов осуществляли экстракцией хлороформ/метанолом по методу Фолча.

Жирнокислотный состав определяли на газовом хроматографе НP 6890 фирмы «Hewlett Parkard».

Измерения проводились с трехкратной повторностью. Обработка полученного материала проводилась с помощью общепринятого параметрического метода (t-критерий Стьюдента) с применением программы «Statistica 10.0».

\section{Результаты и обсуждение}

\section{Результать}

При создании новых заводских линий калмыцкой породы ставилась цель закрепить у потомков Пирата 6626 высокую энергию роста и длиннотелость, Похвального 8643 - укрупненный тип телосложения и интенсивную долгорослость, а у Ожога 6136 - скороспелость и лучшее развитие тазового пояса.

Для оценки мясной продуктивности, морфологического состава туш, физико-химического, аминокислотного состава мышечной ткани, состава жирных кислот внутримышечного жира, был проведен контрольный убой молодняка (бычков) в 15-месячном возрасте разной линейной принадлежности.

Результаты контрольного убоя представлены в таблице 1.

Результаты контрольного убоя показали, что более высокую массу парной туши имели бычки линии
Average samples of ground meat passed through meat grinder with a hole diameter of $3 \mathrm{~mm}$ and intramuscular fat samples obtained from all three groups were studied. Ground meat was mixed well and average sample of 400 g was taken.

The content of amino acids and their ratio were studied using Capel 105/105M capillary electrophoresis system. The comparison was made according to the amino acid scale of the Food Committee of the World Health Organization (FAO/WHO).

Lipid isolation from the samples was carried out by chloroform/methanol extraction using the Folch method.

Fatty acid composition was determined using HP 6890 gas chromatograph by Hewlett Packard.

The measurements were carried out in triplicate. The processing of data obtained was carried out with the help of the standard parametric method (Student's t-test) using Statistica 10.0 software.

\section{Results and discussion}

\section{Results}

When creating new stud lines of Kalmyk breed, the goal was to consolidate high growth characteristics and long body in the descendants of Pirat 6626 line, enlarged constitution and intensive prolonged growth in Pokhvalny 8643 line, and early maturing and best development of pelvic girdle in Ozhog 6136 line.

To assess meat productivity, morphological composition of carcasses, physical and chemical properties, amino acid composition of muscle tissue, fatty acid composition of intramuscular fat, control slaughter of young animals (15 months of age) of different lines was carried out.

The results of control slaughter are presented in Table 1.

The results of control slaughter showed that the Pirat 6626 bulls had a higher fresh carcass weight, $215.9 \mathrm{~kg}$ in av-

Table 1. Meat productivity in young cattle of new stud lines

Таблица 1. Мясная продуктивность молодняка крупного рогатого скота новых заводских линий

\begin{tabular}{|c|c|c|c|}
\hline \multirow{2}{*}{ Parameter | Показатель } & \multicolumn{3}{|c|}{$\begin{array}{l}\text { New stud lines of Kalmyk breed | Заводские линии } \\
\text { калмыцкой породы крупного рогатого скота }\end{array}$} \\
\hline & $\begin{array}{c}\text { Pirat 6626| } \\
\text { Пирата } 6626\end{array}$ & $\begin{array}{l}\text { Pokhvalny } 8643 \text { | } \\
\text { Похвального } 8643\end{array}$ & $\begin{array}{l}\text { Ozhog } 6136 \\
\text { Ожога } 6136\end{array}$ \\
\hline Pre-slaughter live weight, kg | Предубойная живая масса, кг & $400.0 \pm 4.12$ & $392.5 \pm 4.30$ & $396.7 \pm 4.39$ \\
\hline Fresh carcass weight, $\mathrm{kg}$ | Масса парной туши, кг & $215.9 \pm 2.31$ & $212.4 \pm 1.96$ & $212.6 \pm 1.70$ \\
\hline Internal raw fat weight, kg | Масса внутреннего жира, кг & $8.0 \pm 0.56$ & $9.0 \pm 0.87$ & $10.7 \pm 0.39$ \\
\hline Dressed weight, kg | Убойная масса, кг & $223.9 \pm 2.87$ & $221.4 \pm 2.83$ & $223.3 \pm 2.09$ \\
\hline Carcass yield, \% | Выход туши, \% & 54.0 & 54.1 & 53.6 \\
\hline Internal raw fat yield, \% | Выход внутреннего жира, \% & 2.0 & 2.3 & 2.7 \\
\hline Slaughter yield, \% | Убойный выход, \% & 56.0 & 56.4 & 56.3 \\
\hline
\end{tabular}


Table 2. Morphological composition of carcasses from experimental young bulls

Таблица 2. Морфологический состав туш подопытных бычков

\begin{tabular}{|c|c|c|c|}
\hline \multirow{2}{*}{ Parameter | Показатель } & \multicolumn{3}{|c|}{$\begin{array}{l}\text { New stud lines of Kalmyk breed | Заводские линии } \\
\text { калмыцкой породы крупного рогатого скота }\end{array}$} \\
\hline & $\begin{array}{c}\text { Pirat } 6626 \mid \\
\text { Пирата } 6626\end{array}$ & $\begin{array}{c}\text { Pokhvalny } 8643 \text { | } \\
\text { Похвального } 8643\end{array}$ & $\begin{array}{l}\text { Ozhog } 6136 \\
\text { Ожога } 6136\end{array}$ \\
\hline Chilled carcass weight, kg | Масса охлажденной туши, кг & $211.6 \pm 2.82$ & $207.4 \pm 3.26$ & $208.3 \pm 3.17$ \\
\hline Deboned meat weight, kg | Масса обваленного мяса, кг & $74.8 \pm 2.06$ & $71.0 \pm 2.56$ & $71.6 \pm 1.84$ \\
\hline Deboned meat yield, \% | Выход обваленного мяса, \% & 82.6 & 82.4 & 82.3 \\
\hline Bone weight, kg | Масса костей, кг & $36.8 \pm 0.76$ & $36.4 \pm 0.69$ & $36.8 \pm 0.84$ \\
\hline Bone yield, \% | Выход костей, \% & 17.4 & 17.6 & 17.7 \\
\hline Meatness | Коэффициент мясности & 4.75 & 4.70 & 4.66 \\
\hline
\end{tabular}

Пирата 6626 - в среднем 215,9 кг; Похвального 8643 и Ожога 6136 ниже - соответственно 212,4 и 212,6 кг.

Выход внутреннего жира был выше у бычков линии Ожога 6136 и составил 2,7\%, против 2,0 и 2,3\%, у бычков линии Пирата 6626 и Похвального 8643.

По убойной массе и убойному выходу бычки новых линий отличались незначительно и составили 221,4223,9 кг и 56,0\%- 56,4\% соответственно.

Оценка морфологического состава туш у бычков новых линий приведена в таблице 2 .

Туши всех подопытных животных при убое характеризовались хорошим выходом обваленного мяса $(82,3-82,6 \%)$ при относительно небольшом содержании костей $(17,4-17,7 \%)$.

Наиболее важным качественным показателем туши является коэффициент мясности, то есть отношение массы обваленного мяса к массе костей. Выход обваленного мяса на 1 кг костей у бычков линии Пирата 6626 составил 4,75, а у бычков линии Похвального 8643 и Ожога 6136 составил соответственно 4,70 и 4,66.

При оценке мясной продуктивности учитывали химический состав образцов средней пробы полученного обваленного мяса (таблица 3 ). erage, while in Pokhvalny 8643 and Ozhog 6136 lines these values were lower, 212.4 and $212.6 \mathrm{~kg}$, respectively.

Internal raw fat yield was higher for the bulls of Ozhog 6136 line and amounted to $2.7 \%$ against 2.0 and $2.3 \%$, for Pirat 6626 and Pokhvalny 8643 bulls.

Dressed weight and slaughter yield differed insignificantly and amounted to 221.4 to $223.9 \mathrm{~kg}$ and $56.0 \%$ to $56.4 \%$, respectively.

Evaluation of morphological composition of carcasses from young bulls of new lines is given in Table 2 .

At slaughter, carcasses of all experimental animals were characterized by a good yield of deboned meat (82.3 to $82.6 \%$ ) with a relatively small bone content (17.4 to $17.7 \%$ ).

The most important qualitative indicator of carcass is meatness, that is the ratio of deboned meat weight to bone weight. Deboned meat yield per $1 \mathrm{~kg}$ of bones in Pirat 6626 bulls was 4.75, while in Pokhvalny 8643 and Ozhog 6136 lines it was 4.70 and 4.66 , respectively.

When evaluating meat productivity, the chemical composition of average sample of obtained deboned meat was taken into account (Table 3).

Table 3. Physical and chemical parameters of average sample of deboned meat from young bulls of new lines of Kalmyk breed Таблица 3. Физико-химические показатели средней пробы обваленного мяса бычков новых линий калмыцкой породы

\section{Parameter | Показатель}

New stud lines of Kalmyk breed | Заводские линии калмыцкой породы крупного рогатого скота

Pirat 6626 | Pokhvalny 8643 | Ozhog 6136 |

Пирата 6626 Похвального 8643 Ожога 6136

\section{$\mathrm{pH} \mid \mathrm{pH}$}

Moisture content, \% | Массовая доля влаги, \%

Dry matter,\% | Сухое вещество, \%

\begin{tabular}{|c|c|c|}
\hline $5.9 \pm 0.05$ & $5.7 \pm 0.03$ & $5.8 \pm 0.5$ \\
\hline $75.06 \pm 0.09$ & $73.62 \pm 0.14$ & $74.22 \pm 0.06$ \\
\hline $24.94 \pm 0.56$ & $26.38 \pm 0.94$ & $25.78 \pm 0.26$ \\
\hline $20.95 \pm 0.27$ & $23.41 \pm 0.44$ & $21.75 \pm 0.11$ \\
\hline $2.84 \pm 0.01$ & $1.97 \pm 0.03$ & $2.99 \pm 0.02$ \\
\hline $1.15 \pm 0.28$ & $1.00 \pm 0.47$ & $1.04 \pm 0.13$
\end{tabular}

Including, \%: | В том числе, \%:

protein $\mid$ белок

fat $\mid$ жир

ash | зола

Water binding capacity, \% of total moisture |

Влагосвязывающая способность, \% к общей влаге

\begin{tabular}{|l|l|l|}
\hline $67.04 \pm 0.02$ & $65.08 \pm 0.12$ & $65.95 \pm 0.12$
\end{tabular}

Juice loss during cooking, \% | Потери сока при варке, \%

$22.64 \pm 0.08$

$23.40 \pm 0.11$

$23.54 \pm 0.13$

Energy value, $\mathrm{kcal}(\mathrm{kJ}) / 100 \mathrm{~g}$ |

Энергетическая ценность, ккал (кДж) /100 г

$109 / 461$

$111 / 471$

$114 / 480$ 
По содержанию в мясе сухого вещества наиболее высокий показатель у бычков линии Похвального $8643-26,38 \%$. Это произошло, в основном, за счет более высокого содержания белка в мясе у бычков линии Похвального 8643 (23,41\%), чем у бычков линии Пирата 6626 и Ожога 6136 (20,95 и 21,75\%). При этом, содержание жира у бычков линии Пирата 6626 и Ожога 6136 было выше (2,84 и 2,99\%), чем у бычков линии Похвального 8643 (1,97\%).

Эти признаки являются косвенными показателями зрелости животных, так как известно, что отложение жира в условиях нормального кормления и содержания животных связано с изменением обмена веществ в организме. У скороспелых животных понижается интенсивность роста мускулатуры и других тканей, но усиливается накопление жира [10].

Важнейшим фактором, определяющим качество мяса является влагосвязывающая способность. Сочность, нежность, вкус и другие технологические свойства во многом зависят от способности мяса удерживать воду.

У бычков линии Пирата 6626 влагосвязывающая способность выше на 1,96 и 1,09\%, чем у бычков линии Похвального 8643 и Ожога 6136, что связано с более высоким значением $\mathrm{pH}$.

Потери сока при варке в тоже время, у бычков линии Пирата 6626 ниже на 0,76 и 0,90\%, чем у бычков линии Похвального 8643 и Ожога 6136.

По энергетической ценности образцы мяса отличались незначительно. Энергетическая ценность 100 г говядины составила - 109/461 ккал/кДж линии Пирата 6626; 111/472 ккал/кДж - Похвального 8643; 114/480 ккал/кДж - Ожога 6136, что свидетельствует о диетических свойствах мяса бычков новых линий.

Анализ аминокислотного состава в мясе бычков новых линий показал наличие в нем всех незаменимых кислот (таблица 4).

В белках мяса животных всех трех линий содержание незаменимых аминокислот превышает рекомен-
The highest dry matter content was in meat from Pokhvalny 8643 bulls, which amounted to $26.38 \%$. This was, basically, due to the higher protein content in meat from Pokhvalny 8643 bulls (23.41\%) compared to meat from Pirat $6626(20.95 \%)$ and Ozhog $6136(21.75 \%)$ bulls. At the same time, fat content in Pirat 6626 and Ozhog 6136 bulls was higher (2.84 and 2.99\%) than in Pokhvalny 8643 bulls (1.97\%).

These characteristics are indirect indicators of animal maturity, since it is known that deposition of fat under conditions of normal feeding and maintenance is associated with changes in metabolism. In early-maturing animals, growth intensity of muscles and other tissues decreases, but the accumulation of fat increases [10].

The most important factor determining the meat quality is the water binding capacity. Juiciness, tenderness, taste and other technological properties largely depend on the ability of meat to retain water.

In Pirat 6626 line, water binding capacity is $1.96 \%$ and $1.09 \%$ higher than in Pokhvalny 8643 and Ozhog 6136 lines, respectively, which is associated with a higher $\mathrm{pH}$.

At the same time, juice loss during cooking in Pirat 6626 bulls is $0.76 \%$ and $0.90 \%$ lower than in Pokhvalny 8643 and Ozhog 6136 animals.

Energy value in meat samples differed insignificantly. Energy value in $100 \mathrm{~g}$ of beef was $109 / 461 \mathrm{kcal} / \mathrm{kJ}$ in Pirat 6626 line; 111/472 kcal/kJ in Pokhvalny 8643 line; 114/480 $\mathrm{kcal} / \mathrm{kJ}$ in Ozhog 6136 line, which indicates the nutritional properties of meat from bulls of new lines.

Analysis of the amino acid composition in the meat from bulls of new lines showed the presence of all essential acids (Table 4).

In animal protein of all three lines, the content of essential amino acids exceeds the level recommended by FAO/

Table 4. Essential amino acid content in proteins of muscle tissues from different breeds, $\mathrm{mg}$ per $1 \mathrm{~g}$ of protein

Таблица 4. Содержание незаменимых аминокислот в белках мышечной ткани бычков различных пород, мг на 1 г белка

\begin{tabular}{|c|c|c|c|c|}
\hline \multirow{2}{*}{ Amino acid | Аминокислота } & \multicolumn{4}{|c|}{ Essential amino acid content | Содержание незаменимых аминокислот } \\
\hline & $\begin{array}{c}\text { The FAO/WHO standard | } \\
\text { Эталон по ФАО/BO3 }\end{array}$ & $\begin{array}{c}\text { Pirat 6626 | } \\
\text { Пирата 6626 }\end{array}$ & $\begin{array}{c}\text { Pokhvalny } 8643 \text { | } \\
\text { Похвального } 8643\end{array}$ & $\begin{array}{l}\text { Ozhog 6136 | } \\
\text { Ожога } 6136\end{array}$ \\
\hline Lysine | Лизин & 55 & $61 \pm 0.98$ & $59 \pm 0.89$ & $57 \pm 0.82$ \\
\hline Leucine | Лейцин & 70 & $85 \pm 0.77$ & $73 \pm 1.13$ & $71 \pm 0.83$ \\
\hline Isoleucine | Изолейцин & 40 & $49 \pm 0.59$ & $45 \pm 0.45$ & $49 \pm 0.64$ \\
\hline Valine | Валин & 50 & $60 \pm 0.62$ & $55 \pm 0.39$ & $57 \pm 0.89$ \\
\hline Methionine + cysteine | Метионин+цистеин & 35 & $41 \pm 0.30$ & $38 \pm 0.28$ & $39 \pm 0.66$ \\
\hline Threonine | Треонин & 40 & $46 \pm 0.29$ & $42 \pm 0.50$ & $46 \pm 0.27$ \\
\hline Tryptophan | Триптофан & 10 & $13 \pm 0.84$ & $13 \pm 0.16$ & $15 \pm 0.18$ \\
\hline Phenylalanine + tyrosine | Фенилаланин + тирозин & 60 & $67 \pm 0.73$ & $63 \pm 0.49$ & $65 \pm 0.36$ \\
\hline
\end{tabular}


Table 5. Biological value indicators of beef muscle tissue proteins

Таблица 5. Показатели биологической ценности белков мышечной ткани говядины

\begin{tabular}{|c|c|c|c|}
\hline \multirow[b]{2}{*}{ Amino acid | Аминокислота } & \multicolumn{3}{|c|}{ Amino acid score, \% | Аминокислотный скор (AC), \% } \\
\hline & $\begin{array}{c}\text { Pirat } 6626 \mid \\
\text { Пирата } 6626\end{array}$ & $\begin{array}{c}\text { Pokhvalny } 8643 \text { | } \\
\text { Похвального } 8643\end{array}$ & $\begin{array}{c}\text { Ozhog 6136 } \\
\text { Ожога } 6136\end{array}$ \\
\hline Lysine | Лизин & 110.9 & 107.3 & 103.0 \\
\hline Leucine | Лейцин & 121.4 & 104.3 & 121.4 \\
\hline Isoleucine | Изолейцин & 122.5 & 112.5 & 122.5 \\
\hline Valine | Валин & 120.0 & 110.0 & 114.0 \\
\hline Methionine + cysteine $\mid$ Метионин + цистеин & 117.1 & 108.6 & 111.4 \\
\hline Threonine | Треонин & 115.0 & 105.0 & 115.0 \\
\hline Tryptophan | Триптофан & 130.0 & 130.0 & 150.0 \\
\hline Phenylalanine + tyrosine | Фенилаланин + тирозин & 111.7 & 105.0 & 108.3 \\
\hline Amino acid score difference, \% | KPAC, \% & 18.6 & 10.3 & 18.3 \\
\hline Biological value, \% | БЦ, \% & 81.4 & 89.7 & 81.7 \\
\hline
\end{tabular}

дуемый ФАО/ВОЗ для человека, что говорит о том, что полученное мясо сбалансировано по аминокислотному составу и усвояемость белков животного происхождения равна $100 \%$ (таблица 5).

Анализ аминокислотного скора, свидетельствующего о полноценности белка, показал, что в белках говядины всех линий бычков не имеется лимитирующих аминокислот. Максимальный аминокислотный скор лизина в белках наблюдался у животных линии Пирата 6626. Лейцина и изолейцина выше в белках мышечной ткани бычков линий Пирата 6626 и Ожога 6136.

Полноценного белка валина по результатам расчета скора было больше в белках мышц животных линий Пирата 6626, их скор составил 120,0\%, Похвального 8643 - 110,0\%, Ожога 6136 - 114,0\%. Скор аминокислоты метионин и треонин с меньшей разницей к эталонному белку на стороне бычков линии Похвального 8643. Минимальная разница скора фенилаланина с эталонным белком наблюдалась также у бычков линии Похвального 8643 и составила - 105,0\%.

По результатам расчета биологической ценности белка более сбалансированным соотношением незаменимых аминокислот обладает линия Похвального $8643-89,7 \%$, тогда как у линии Пирата 6626 и ожога 6136 - 81,4 и $81,7 \%$ соответственно.

Различия в составе жирных кислот были небольшие.

Состав жирных кислот внутримышечного жира представлен в таблице 6 .

Оценка содержания полиненасыщенных кислот позволила отметить достаточно высокую их концентрацию во внутримышечном жире бычков всех пород. Так, общее их содержание в образцах линии Пирата 6626 составило 5,24\%, Похвального 8643- 5,72\% и Ожога $6136-5,39 \%$. Различия были несущественные, но все же прослеживалось превосходство данных пока-
WHO for humans, which means that the meat obtained is balanced by amino acid composition and that the digestibility of these animal proteins is $100 \%$ (Table 5).

Analysis of the amino acid score indicating the protein value showed that the beef proteins of all three lines had no limiting amino acids. The maximum lysine amino acid score was observed in proteins of animals in Pirat 6626 line. Leucine and isoleucine content was higher in muscle proteins of Pirat 6626 and Ozhog 6136 lines.

Valine content was higher in muscle proteins of animal from Pirat 6626 line with score of $120.0 \%$ compared to Pokhvalny 8643 (110.0\%) and Ozhog 6136 (114.0\%). Methionine and threonine amino acid scores had smaller difference from the reference protein in Pokhvalny 8643 line. The minimum difference from the reference protein in phenylalanine amino acid score was also observed in Pokhvalny 8643 line (105.0\%).

According to calculation results of protein biological value, Pokhvalny 8643 line had more balanced ratio of essential amino acids (89.7\%), while in Pirat 6626 and Ozhog 6136 lines this parameter was $81.6 \%$ and $81.7 \%$, respectively.

Differences in fatty acid composition were insignificant.

Fatty acid composition of intramuscular fat is presented in Table 6.

Estimation of polyunsaturated fatty acid content sowed their high concentration in intramuscular fat of all breeds. Thus, their total content in Pirat 6626 line samples was 5.24\%, and in Pokhvalny 8643 and Ozhog 6136 lines this value was $5.72 \%$ and $5.39 \%$, respectively. The differences were insignificant, but nevertheless, the superiority of these indicators in Pokhvalny 8643 line by $0.48 \%$ and 
Table 6. Fatty acid composition of intramuscular fat, $\%$

Таблица 6. Состав жирных кислот внутримышечного жира, \%

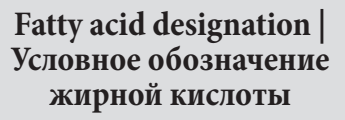

Fatty acid name | Наименование жирной кислоты (ЖК)
New stud lines of Kalmyk breed | Линия

\begin{tabular}{|c|c|c|}
\hline $\begin{array}{c}\text { Pirat 6626 } \\
\text { Пирата 6626 }\end{array}$ & $\begin{array}{c}\text { Pokhvalny 8643 } \\
\text { Похвального 8643 }\end{array}$ & $\begin{array}{c}\text { Оzhog 6136 } \\
\text { Ожога 6136 }\end{array}$ \\
\hline $44.89 \pm 0.47$ & $44.24 \pm 0.45$ & $41.82 \pm 0.48$ \\
\hline $2.88 \pm 0.16$ & $3.23 \pm 0.14$ & $2.61 \pm 0.15$ \\
\hline $25.02 \pm 0.25$ & $24.23 \pm 0.26$ & $23.12 \pm 0.23$ \\
\hline $16.99 \pm 0.21$ & $16.78 \pm 0.25$ & $16.09 \pm 0.24$ \\
\hline $39.76 \pm 0.33$ & $38.76 \pm 0.32$ & $39.38 \pm 0.31$ \\
\hline $0.19 \pm 0.14$ & $0.27 \pm 0.13$ & $0.21 \pm 0.11$ \\
\hline $3.84 \pm 0.02$ & $3.98 \pm 0.04$ & $4.05 \pm 0.01$ \\
\hline $35.73 \pm 0.33$ & $34.51 \pm 032$ & $35.12 \pm 0.31$ \\
\hline $5.24 \pm 0.18$ & $5.72 \pm 0.16$ & $5.39 \pm 0.17$ \\
\hline $3.89 \pm 0.11$ & $4.12 \pm 0.13$ & $3.77 \pm 0.12$ \\
\hline $0.84 \pm 0.01$ & $0.98 \pm 0.08$ & $0.90 \pm 0.03$ \\
\hline $0.51 \pm 0.18$ & $0.62 \pm 0.11$ & $0.72 \pm 0.09$ \\
\hline
\end{tabular}

зателей линии Похвального 8643 над линией Пирата 66,26 и линией Ожога 6136 на 0,48 и 0,33\% соответственно. Во внутримышечном жире бычков олеиновая жирная кислота имела самое высокое содержание от $34,51 \%$ до $35,73 \%$, содержание пальмитиновой кислоты составило 23,12 - 25,02\%, стеариновой от $16,09 \%$ до 16,99\%. Внутримышечный жир бычков линии Ожога 6736 характеризовался меньшим содержанием насыщенных жирных кислот по сравнению со сверстниками из других линий, по пальмитиновой кислоте на $1,90 \%$ и $1,11 \%$, стеариновой - 0,90\% и $0,69 \%$ и миристиновой $-0,27 \%$ и $0,62 \%$ соответственно.

Дегустационная оценка качества отварного мясаговядины и мясного бульона от молодняка крупного рогатого скота калмыцкой породы новых линий «хорошее» и «очень хорошее».

\section{Обсуждение}

Живая масса животных является породным, хозяйственным и селекционным признаком, подверженным постоянным изменениям. У растущего молодняка изменения живой массы связаны с накоплением органических веществ различного состава, с ростом отдельных органов, тканей и отложением запасных веществ. Однако увеличение живой массы не отражает преобразований, которые происходят в туше и тканях.

Для селекционного процесса мясные достоинства, скороспелость и готовность животного к убою необходимо оценить не только по достигнутым к определенному возрасту живой массе и по соотношению в туше мышц, жира, костей, сухожилий [11].

При откорме молодняка нужно стремиться к получению в молодом возрасте крупных животных с ми-
0.33\% compared to Pirat 6626 and Ozhog 6136 lines, respectively, was observed. In intramuscular fat of bulls, oleic fatty acid had the highest content (34.51\% to $35.73 \%$ ), palmitic acid content was $23.12 \%$ to $25.02 \%$, stearic acid content was $16.09 \%$ to $16.99 \%$. Intramuscular fat of Ozhog 6736 line was characterized by a lower content of saturated fatty acids compared to other lines, palmitic acid was lower by $1.90 \%$ and $1.11 \%$, stearic acid was lower by $0.90 \%$ and $0.69 \%$ and myristic acid was lower by $0,27 \%$ and $0.62 \%$, respectively.

Sensory assessment of boiled beef and meat broth quality from new lines of Kalmyk young cattle was «good» and «very good.

\section{Discussion}

Live weight of animals is economic and breeding characteristic subject to constant changes. In growing young bulls, changes in live weight are associated with accumulation of different organic substances, with growth of individual organs and tissues and with deposition of reserve energetic substances. However, the increase in live weight does not reflect the transformations that occur in carcass and tissues.

For breeding process, meat content, early maturity and readiness for slaughter must be assessed not only by live weight in a certain age and by the ratio of muscles, fat, bones, and tendons in the carcass [11].

When fattening young bulls, we should obtain large animals at young age with a minimum content of low value 
нимальным содержанием малоценных частей в туше и желательным соотношением белка и жира. Процессы роста и формирования тканей в организме молодняка у различных пород и внутрипородных структурных элементов происходят с различной интенсивностью и заканчиваются в разное время [12-13].

Изучение мясной продуктивности и морфологического состава туш дает преимущественно количественную характеристику мясных качеств животного.

Вкусовые качества мяса и его пищевая ценность зависят от химического состава мяса, содержания в нем влаги, белков, жиров, аминокислотного и жирнокислотного состава и др.

Полную оценку мясной продуктивности и пищевой ценности мяса новых линий можно дать лишь на основании количественной оценки всех этих факторов.

\section{Выводы:}

- Важнейшим направлением увеличения производства говядины является создание новых линий и повышение продуктивных качеств крупного рогатого скота калмыцкой породы.

- Туши бычков новых заводских линий калмыцкой породы: Пирата 6626, Похвального 8643 и Ожога 6136 при убое характеризовались хорошим выходом обваленного мяса (82,3-82,6\%) при относительно небольшом содержании костей $(17,4-17,6 \%)$.

- Анализ химического состава обваленного мяса животных новых линий показал более высокое содержания белка в мясе у бычков линии Похвального 8643 (23,41\%), чем у бычков линии Пирата 6626 и Ожога 6136 (20,95 и 21,75\%).

- В белках мяса животных трех линий содержание незаменимых аминокислот превышает рекомендуемый ФАО/ВОЗ для человека, не имеется лимитирующих аминокислот.

- Мясо бычков линии Похвального 8643 являлось наиболее биологически полноценным по аминокислотному составу и их соотношению - 89,7\%, тогда как у линии Пирата 6626 и Ожога 6136 - 81,4 и $81,7 \%$ соответственно.

- Различия в составе жирных кислот во внутримышечном жире бычков всех линий были небольшие. По содержанию полиненасыщенных кислот линия Похвального 8643 - 5,72\% превосходит линию Пирата 6626 на $0,48 \%$ и Ожога 6136 на $0,33 \%$.

- Внутримышечный жир бычков линии Ожога 6136 характеризовалась наименьшим содержанием насыщенных жирных кислот.

- Разведение и накопление крупного рогатого скота новых заводских линий позволит поставлять для убоя и получать высококачественную говядину от 15-месячных потомков Пирата 6626 и Ожога 6136. Бычков линии Похвального 8643 можно интенсивно выращивать до более старшего возраста и получать тяжеловесную не пережиренную тушу. parts in carcass and the desired ratio of protein and fat. The processes of growth and formation of tissues in the body of young animals of different breeds and lines occurs with different intensity and stops at different time [12-13].

The study of meat productivity and morphological composition of carcasses gives a predominantly quantitative characterization of beef bull quality.

Meat taste and nutritional value depend on the chemical composition, moisture, protein and fat content, amino acid and fatty acid composition, etc.

Full evaluation of meat productivity and nutritional value of meat from new lines is possible only on the basis of quantitative evaluation of all these factors.

\section{Conclusion:}

- To increase the production of beef, the most important activity is the development of new lines and the increase of productivity characteristics of Kalmyk cattle.

- At slaughter, carcasses of young bulls from new stud lines of Kalmyk breed: Pirat 6626, Pokhvalny 8643 and Ozhog 6136 are characterized by good yield of deboned meat ( 82.3 to $82.6 \%)$ with a relatively small bone content (17.4 to $17.6 \%)$.

- Chemical composition analysis of deboned meat from new lines showed a higher protein content in the meat of Pokhvalny 8643 bulls (23.41\%) compared to Pirat 6626 and Ozhog 6136 (20.95 and 21.75\%) bulls.

- In proteins of animals from all three lines, the content of essential amino acids exceeds the levels recommended by FAO/WHO for humans; there are no limiting amino acids.

- Meat of Pokhvalny 8643 bulls is the most biologically valuable in terms of amino acid composition and their ratio $(89.7 \%)$, while these values for Pirat 6626 and Ozhog 6136 lines are $81.4 \%$ and $81.7 \%$, respectively.

- Differences in fatty acid composition in intramuscular fat of the bulls in all three lines were insignificant. The content of polyunsaturated acids in Pokhvalny 8643 line is 5.72\%, which is higher than in Pirat 6626 and Ozhog 6136 lines by $0.48 \%$ and $0.33 \%$, respectively.

- Intramuscular fat from Ozhog 6136 bulls is characterized by the lowest content of saturated fatty acids.

- Breeding and increasing the cattle number of new stud lines will allow producing high-quality beef from 15-month-old bulls of Pirat 6626 and Ozhog 6136 lines. Bulls of Pokhvalny 8643 line may be intensively grown up to an older age to receive heavy carcass with no fat excess. 


\section{БИБЛИОГРАФИЧЕСКИЙ СПИСОК}

1. Кавардаков, В.Я. Современное состояние и проблемы технологического развития скотоводства Российской Федерации / В.Я. Кавардаков, А.И. Бараников, А.Ю. Колосов, А.Ф.Кайдалов, Г.М. Бажов, В.Н. Бевзюк, О.В. Степанова // Аграрный вестник Урала. - 2013. - Т. 9. - № 115. C. 33-36.

2. Колосов, Ю.А. Влияние ритмичного кормления на эффективность производства говядины / Ю.А. Колосов, И.В. Капемист, П.И. Зеленков, П.С. Кобыляцкий // Аграрный вестник Урама. - 2010. - Т. 12. - № 79. - С. 44-46.

3. Крупный рогатый скот. Каммыцкая порода коров. [Электронный ресурс: http://fermerznaet.com/zhivotnovodstvo/krs/ kalmyckaya-poroda.html. Аата обращения 01.06.2017]

4. Каюмов, Ф.Г. Каммыцкая порода КРС в России: современное состояние / Ф.Г. Каюмов // Нивы Зауралья. - 2014. №10 (121). - C. 74-76

5. ААжаев, В.И. Каммыцкая порода мясного скота / В.И. ААжаев // Вестник мясного скотоводства. - 2010. - Т. 3. № 63. - C. 24-34.

6. Приступа, Е.Н. Организационно-экономическая оценка вновь создаваемых заводских миний скота калмыцкой пороАы. / Е.Н. Приступа, А.В. Казьмин, В.Н. Приступа. [Электронный ресурс: http://www.rusagroug.ru/articles/2087 . Аата обращения 10.05.2017]

7. Еременко, В. К. Совершенствование мясных пород скота / В.К. Еременко, А. Г. Зелепухин // Молочное и мясное скотоводство. - 2005. - № 6. - С. 17-19.

8. Руководство по методам анализа качества и безопасности пищевых продуктов / под реА. И. М. Скурихина, В. А. Туте^ьяна. - М. : Брандес-Медицина, 1998. - 341 с.

9. Аисицын А.Б. Методы практической биотехнологии. Анамиз компонентов и микропримесей в мясных и Аругих пищевых продуктах /А.Б. Аисицын, А.Н. Иванкин, А.А. НекАюдов. -М.: ВНИИМП, - 2002. - 408 c.

10. Колосов, Ю.А. Некоторые особенности экстерьера момодняка различного происхождения / Ю.А. КолосоВ, И.В. Засемчук, Т.С. Романец, М.Е. Маенко // Вестник Аонского государственного аграрного университета. -2014 . - № 2 (12). - C. 19-25.

11. Мусаев Ф.А., Морозова Н.И. Инновационные технологии в производстве говядины. Монография. Рязань: РГАТУ. 2014 - 160 с. ISBN 978-5-98660-200-4.

12. Бельков, Г.В. Использование зарубежных пород Аля повышения продуктивности отечественного крупного рогатого скота / Г.В. Бельков // Вестник мясного скотоводства. - 2010. T. 3. - № 63. - C. 107-114.

13. Половинко, А. М. Совершенствование животных калмыцкой породы на основе высокопродуктивных внутрипородных типов / И.М. Половинко, Ф.Г. Каюмов, Е.А. Кущ, Г.П. Аегошин, М.Ю. Половинко // Молочное и мясное скотоводство. 2016. - № 6. - C. 11-14.

\section{REFERENCES}

1. Kavardakov, V.Ya. The modern condition and problems the technological development of cattle breeding in Russian Federation / V.Ya. Kavardakov, A.I. Baranikov, A.Y. Kolosov, A.F. Kaydalov, G.M. Bazhov, V.N. Bevzyuk, O.V. Stepanova// Agrarian Bulletin of the Urals. - 2013. - Vol. 9. - № 115. - P. 33-36.

2. Kolosov, J.A. Influence of rhythmical feeding on production efficiency of beef / J.A. Kolosov, I.V. Kapelist, P.I. Zelenkov, P.S. Kobylyatski // Agrarian Bulletin of the Urals. - 2010. - Vol. 12. № 79. - P. 44-46.

3. Cattle. The Kalmyk breed cows. [Electronic resource: http:// fermerznaet.com/zhivotnovodstvo/krs/kalmyckaya-poroda.html Access date 01.06.2017]

4. Kayumov, F. G. Kalmyk breed of cattle in Russia: current status / Kayumov F. G.// Niva Urals. - 2014. - № 10 (121). - P. 74-76. 5. Adzhaev, V. I. Kalmyk breed of beef cattle/ V. I. Adzhaev // The herald of beef cattle breeding. -2010 . - Vol. 3. - № 63. P. 24-34.

6. Pristupa, E. N. Organizational-economic evaluation of the newly created factory lines of cattle of Kalmyk breed. / E.N. Pristupa, A.V. Kazmin, V.N. Pri-stupa. [Electronic resource: http:// www.rusagroug.ru/articles/2087. Access date 10.05.2017]

7. Eremenko, V.K. Improvement of meat breeds of cattle / V.K. Eremenko, A. G. Zelepugin // Dairy and Beef Cattle Breeding. -2005 . - №. 6. - P. 17-19.

8. Manual of methods of analysis of the quality and safety of food products / Under the editorship I.M. Skurikhin, Tutelian V.A. - M.: Brandes-Medicine, 1998. - 84-93.

9. Lisitsyn, A. B., Methods of practical biotechnology. Analysis of components and traces in meat and other food products / A.B. Lisitsyn, A.N. Ivankin, A.D. Nekludov. - M.: VNIIMP, - 2002. $408 \mathrm{p}$.

10. Kolosov, Yu.A. Exterior features some young different origin / Yu.A. Kolosov, I.V. Zasemchuk, T.S. Romanets, M.E. Maenko // Vestnik of Don State Agrarian University. - 2014. - № 2 (12). P. 19-25.

11. Musaev F. A., Morozova N. I. Innovative technologies in beef production. Monograph. Ryazan: RGATU. $-2014-160$ p. ISBN 978-5-98660-200-4

12. Belkov, G. V. Use of foreign breeds for the productivity increase of domestic beef cattle / G.V. Belkov // The herald of beef cattle breeding. -2010 . - Vol. 3. - № 63. - P. 107-114.

13. Polovinko, L.M. Improvement of animal of Kalmyk breed on the base of high-productive intr-breed types / L.M. Polovinko, F.G. Kayumov, E.D. Kush, G.P. Legoshin, M.U. Polovinko // Dairy and Beef Cattle Breeding. - 2016. - №. 6. - P. 11-14. 


\section{СВЕДЕНИЯ ОБ АВТОРАХ}

Принадлежность к организации

Приступа Василий Николаевич - доктор сельскохозяйственных наук, профессор, кафедра частной зоотехнии и кормления сельскохозяйственных животных, Донской государственный аграрный университет

346493, Ростовская область, Октябрьский район, поселок Персиановский, ул. Кривошлыкова, 24

Тел.: +7-86360- 3-65-08

E-mail: dongau@mail.ru

Колосов Анатолий Юрьевич - кандидат сельскохозяйственных наук, доцент, кафедра информатики, моделирования и статистики, Донской государственный аграрный университет

346493, Ростовская область, Октябрьский район, поселок Персиановский, ул. Кривошлыкова, 24

Тел.: +7-86360- 3-65-08

E-mail: kolosov777@gmail.com.

Торосян Диана Вартановна - аспирант, Донской государственный аграрный университет

346493, Ростовская область, Октябрьский район, поселок Персиановский, ул. Кривошлыкова, 24

Тел.: +7-86360- 3-65-08

E-mail: dongau@mail.ru

Колосов Юрий Анатольевич - доктор сельскохозяйственных наук, профессор, кафедра частной зоотехнии и кормления сельскохозяй-ственных животных, Донской государственный аграрный университет

346493, Ростовская область, Октябрьский район, поселок Персиановский, ул. Кривошлыкова, 24

Тел.: +7-86360- 3-64-89

E-mail:kolosov-dgau@mail.ru

Орлова Ольга Николаевна - кандидат экономических наук, директор, Северо-Кавказский филиал - Всероссийский научно-исследовательский институт мясной промышленности им. В.М. Горбатова

344000, г. Ростов-на-Дону, ул. Лермонтовская, 203

Тел.: +7-863-264-67-62

E-mail:WNIIMP-DON@yandex.ru

Дмитриева Людмила Сергеевна - старший научный сотрудник, Северо-Кавказский филиал - Всероссийский научно-исследовательский институт мясной промышленности им. В. М. Горбатова 344000 , г. Ростов-на-Дону, ул. Лермонтовская, 203

Тел.: +7-863-264-67-62

E-mail:WNIIMP-DON@yandex.ru

Ерошенко Валентина Ивановна - научный сотрудник, СевероКавказский филиал - Всероссийский научно-исследовательский институт мясной промышленности им. В. М. Горбатова

344000 , г. Ростов-на-Дону, ул. Лермонтовская, 203

Тел.: +7-863-264-67-62

E-mail: WNIIMP-DON@yandex.ru

Скрыпник Людмила Владимировна - научный сотрудник, Ceверо-Кавказский филиал - Всероссийский научно-исследовательский институт мясной промышленности им. В. М. Горбатова 344000, г. Ростов-на-Дону, ул. Лермонтовская, 203

Тел.: +7-863-264-67-62

E-mail:WNIIMP-DON@yandex.ru

\section{Критерии авторства}

Авторы в равных долях имеют отношение к написанию рукописи и одинаково несут ответственность за плагиат.

\section{Конфликт интересов}

Авторы заявляют об отсутствии конфликта интересов.

$$
\text { Поступила 31.05.2017 }
$$

\section{AUTHOR INFORMATION \\ Affiliation}

Pristupa Vasily Nikolaevich - doctor of agricultural sciences, professor, chair of private animal husbandry and feeding of agricultural animals, Don State Agrarian University

346493, Rostov region, Oktyabrsky district, village Persianovskiy, Krivoshlykova str., 24

Tel: +7-86360- 3-65-08

E-mail: dongau@mail.ru

Kolosov Anatoly Yurievich - candidate of agricultural sciences, docent, Department of computer science, modeling and statistics, Don State Agrarian University

346493, Rostov region, Oktyabrsky district, village Persianovskiy, Krivoshlykova str., 24

Tel: +7-86360- 3-65-08E-mail: kolosov777@gmail.com.

Torosyan Diana Vartanovna — graduate student, Don State Agrarian University

346493, Rostov region, Oktyabrsky district, village Persianovskiy, Krivoshlykova str., 24

Tel: +7-86360- 3-65-08

E-mail: dongau@mail.ru

Kolosov Yuri Anatolievich - doctor of agricultural sciences, professor, chair of private animal husbandry and feeding of agricultural animals, Don State Agrarian University

346493, Rostov region, Oktyabrsky district, village Persianovskiy, Krivoshlykova str., 24

Tel: +7-86360- 3-64-89

E-mail:kolosov-dgau@mail.ru

Orlova Olga Nikolaevna - candidate of economic sciences, director, The North-Caucasian branch of the V.M. Gorbatov All-Russian Meat Research Institute

344000, Rostov-Don, Lermontovskaya str., 203

Tel: 8-863-264-67-62

E-mail:WNIIMP-DON@yandex.ru

Dmitrieva Lyudmila Sergeevna - senior research scientist, The North- Caucasian branch of the V.M. Gorbatov All-Russian Meat Research Institute

344000, Rostov-Don, Lermontovskaya str., 203

Tel: 8-863-264-67-62

E-mail:WNIIMP-DON@yandex.ru

Eroshenko Valentina Ivanovna - research scientist, The NorthCaucasian branch of the V.M. Gorbatov All-Russian Meat Research Institute

344000, Rostov-Don, Lermontovskaya str., 203

Tel: 8-863-264-67-62

E-mail:WNIIMP-DON@yandex.ru

Skripnik Ludmila Vladimirovna - research scientist, The NorthCaucasian branch of the V.M. Gorbatov All-Russian Meat Research Institute

344000, Rostov-Don, Lermontovskaya str., 203

Tel: 8-863-264-67-62

E-mail: WNIIMP-DON@yandex.ru

\section{Contribution}

The authors equally contributed to the writing of the manuscript and are equally responsible for plagiarism.

\section{Conflict of interest}

The authors declare no conflict of interest.

Received 31.05.2017 